\title{
Parameter estimation and use of gamma interferon assay for the diagnosis of bovine tuberculosis in Brazil ${ }^{1}$
}

\author{
Luciano B. Lopes ${ }^{2 *}$, Telma M. Alves ${ }^{3}$, Ana Paula R. Stynen ${ }^{4}$, Pedro M.P.C. Mota ${ }^{5}$, \\ Rômulo C. Leite ${ }^{6}$ and Andrey P. Lage ${ }^{4}$
}

\begin{abstract}
Lopes L.B., Alves T.M., Stynen A.P.R., Mota P.M.P.C., Leite R.C. \& Lage A.P. 2012. Parameter estimation and use of gamma interferon assay for the diagnosis of bovine tuberculosis in Brazil. Pesquisa Veterinária Brasileira 32(4):279-283. Embrapa Agrossilvipastoril, Rodovia MT 222, km 2,5, Caixa Postal 343, Sinop, MT 78.550-970, Brazil. E-mail: luciano.lopes@embrapa.br

This study aimed to evaluate the interference of tuberculin test on the gamma-interferon (INF $\gamma$ ) assay, to estimate the sensitivity and specificity of the INF $\gamma$ assay in Brazilian conditions, and to simulate multiple testing using the comparative tuberculin test and the INF $\gamma$ assay. Three hundred-fifty cattle from two TB-free and two TB-infected herds were submitted to the comparative tuberculin test and the INF $\gamma$ assay. The comparative tuberculin test was performed using avian and bovine PPD. The INF $\gamma$ assay was performed by the Bovigam ${ }^{\mathrm{TM}}$ kit (CSL Veterinary, Australia), according to the manufacturer's specifications. Sensitivity and specificity of the INF $\gamma$ assay were assessed by a Bayesian latent class model. These diagnostic parameters were also estimate for multiple testing. The results of INF $\gamma$ assay on D0 and D3 after the comparative tuberculin test were compared by the McNemar's test and kappa statistics. Results of mean optical density from INF $\gamma$ assay on both days were similar. Sensitivity and specificity of the INF $\gamma$ assay showed results varying (95\% confidence intervals) from 72 to $100 \%$ and 74 to $100 \%$ respectively. Sensitivity of parallel testing was over $97.5 \%$, while specificity of serial testing was over $99.7 \%$. The INF $\gamma$ assay proved to be a very useful diagnostic method.
\end{abstract}

INDEX TERMS: Mycobacterium bovis, gamma interferon, comparative tuberculin test, diagnosis.

RESUMO.- [Estimação dos parâmetros e uso do teste do interferon gama para o diagnóstico da tuberculose bovina no Brasil.] 0 presente estudo avalia a interferência do teste de tuberculinização no teste do interferon gama

\footnotetext{
${ }^{1}$ Received on August 9, 2011.

Accepted for publication on November 7, 2011

${ }^{2}$ Embrapa Agrossilvipastoril, Rod. MT 222, Km 2,5, Caixa Postal 343, Sinop, MT 78550-970, Brazil. *Corresponding author: luciano.lopes@embrapa.br

${ }^{3}$ Inova Biotecnologia Saúde Animal, Rodovia MG 50, Distrito Industrial, Juatuba, MG 35675-000, Brazil. E-mail: telmarialves@hotmail.com

${ }^{4}$ Laboratório de Bacteriologia Aplicada, Departamento de Medicina Veterinária Preventiva, Escola de Veterinária, Universidade Federal de Minas Gerais (UFMG), Av. Antônio Carlos 6627, Cx. Postal 567, Belo Horizonte, MG 30123-970, Brazil.E-mail: anastynen@gmail.com, alage@vet.ufmg.br

${ }^{5}$ Laboratório Nacional Agropecuário, Ministério da Agricultura, Pecuária e Abastecimento, Av. Rômulo Joviano s/n, Pedro Leopoldo, MG 33600000, Brazil.E-mail: pedrompcmota@yahoo.com.br

${ }^{6}$ Departamento de Medicina Veterinária Preventiva, Escola de Veterinária, UFMG, Avenida Antônio Carlos 6627, Belo Horizonte, MG 31270-010. E-mail: romulo@vet.ufmg.br
}

(INF $\gamma$ ), estima a sensibilidade e a especificidade do INF $\gamma$ em condições brasileiras e simula a utilização dos testes múltiplos usando a tuberculinização comparada e o teste do INF $\gamma$. Trezentos e cinquenta animais oriundos de dois rebanhos livres e dois rebanhos positivos foram submetidos à tuberculinização comparada e ao teste de INF $\gamma$. A tuberculinização comparada foi realizada utilizando PPD aviária e bovina. 0 teste de INF $\gamma$ foi realizado utilizando o kit Bovigam ${ }^{\circledR}$ (CSL Veterinary, Austrália) de acordo com as especificações do fabricante. A sensibilidade e especificidade do teste de INF $\gamma$ foram calculadas pelo Modelo Bayesiano de Classe Latente. Esses parâmetros foram também estimados para os testes múltiplos. Os resultados do teste de INF y no D0 e D3 após o teste de tuberculinização foram comparados pelos testes estatísticos de McNemar e kappa. Os resultados das médias de densidade ótica do teste de INF $\gamma$ em ambos os dias foram similares. A sensibilidade e a especificidade do teste de INF $\gamma$ apresentaram resultados variando (95\% intervalo de confiança) de 72 a 100\% e 74 a 
$100 \%$, respectivamente. A sensibilidade do teste em paralelo foi acima de $97,5 \%$ enquanto a especificidade do teste em série foi acima de 99,7\%. 0 teste do INF $\gamma$ provou ser um método de diagnóstico muito útil.

TERMOS DE INDEXAÇÃOS: Mycobacterium bovis, tuberculose bovina, interferon gama, tuberculinização intradérmica, diagnóstico, Brasil.

\section{INTRODUCTION}

Bovine tuberculosis is still a problem in Brazil. The only comprehensive survey, accomplished in Minas Gerais State in 1999, showed prevalences of infected herds and animals of $5.0 \%$ and $0.81 \%$ respectively (Belchior 2001). Currently other studies are in progress in some Brazilian States. Thus, in 2001, the Ministério da Agricultura, Pecuária e Abastecimento (MAPA) [Brazilian Ministry of Agriculture] started a national program for the control and eradication of brucellosis and tuberculosis (Programa Nacional de Controle e Erradicação de Brucelose e Tuberculose (PNCEBT), which among its policies uses a test-and-slaughter strategy (Brasil 2004). Bovine tuberculosis diagnosis is based on serial testing using caudal fold test, only for beef cattle, and single tuberculin test as screening tests and comparative tuberculin test for confirmatory test (Brasil 2006). However, the PNCEBT is prone to the inclusion of new tests and control strategies in the program, after its validation in Brazil.

In an attempt to detect Mycobacterium bovis-infected cattle as fast as possible, a simple and efficient laboratory method based on the measurement of gamma interferon (INF $\gamma$ ) produced by T lymphocytes of infected animals after in vitro antigenic stimulation was developed (Wood et al. 1990, Rothel et al. 1992, Wood \& Jones 2001). This method showed many advantages compared to the tuberculin test, as just one visit to the farm is needed, repeated testing can be done at any interval because no antigen is inoculated into the animals, it can detect early infections, and its sensitivity is always considered to be similar or greater than that of tuberculin test (Wood et al. 2001, De La Rua-Domenech 2006). Its sensitivity varies from 73.0 to $100 \%$ and its specificity varies between 85.0 and $100 \%$ (Wood\& Jones 2001, De La Rua-Domenech 2006). In Brazil, the sensitivity of the INF $\gamma$ assay was estimated to be $100 \%$ compared to the single tuberculin test (Lilenbaum et al. 1999) and to vary from 71.4 to $91.4 \%$, while the specificity varied between 80.0 and $86.7 \%$, relatively to the comparative tuberculin test at times from the inoculation of tuberculin to 21 days afterwards (Marassi et al, 2010). The use of tests as the tuberculin test that show less than perfect sensitivity and specificity (De La Rua-Domenech 2006, Marassi et al. 2010 ) to estimate the parameters of a new test can introduce bias in the estimated parameters (Enøe et al. 2006, Dendukuri et al. 2009). Moreover, the INF $\gamma$ assay showed decrease rates of sensitivity and specificity with increasing time after tuberculin inoculation (Monaghan et al. 1994), but the effect of recent tuberculin test on the performance of the INF $\gamma$ assay is very conflicting on the literature (Rothel et al. 1992, Whipple et al. 2001, Rangen et al. 2009), probably due to the type of tuberculin test used and testing conditions.
Thus, the aims of present study were (i) to evaluate the interference of tuberculin test on the INF $\gamma$ assay, (ii) to estimate the sensitivity and specificity of the INF $\gamma$ assay in Brazilian conditions, and (iii) to simulate multiple testing using the comparative tuberculin test and the INF $\gamma$ assay in a control and eradication program for bovine tuberculosis (TB).

\section{MATERIALS AND METHODS}

Animals. The three hundred-fifty adult dairy Holstein-Zebu crossbred cattle submitted to the comparative tuberculin test in the study were from four herds in Minas Gerais State, Brazil: two TB-free and two TB-infected herds. The TB-infected herds were selected previously according historical comparative tuberculin test positive results, which showed macroscopic lesions at necropsy and isolation of Mycobacterium bovis from lesions. The TB-free herds were selected previously according historical comparative tuberculin test negative results. Skin test-positive animals from TB-infected herds were enrolled in the present study as infected animals. Skin test-negative animals from TB-free herds were enrolled as TB-negative animals. Skin test-inconclusive animals as well as negative reactions, from any herd, were not enrolled in the study.

Comparative tuberculin test. The comparative tuberculin test was performed according to PNCEBT [2, 3] using avian and bovine PPD (Ministério da Agricultura, Pecuária e Abastecimento - MAPA, Brazil). Skin thickness at injection site was measured before PPD injections and at $72 \pm 6 \mathrm{~h}$ post-inoculation by the same person using the same calipers.

Blood samples. Blood samples were collected through jugular venopunction into heparinized vacuum tubes (Sarstedt, Germany) in two occasions: (i) immediately before the inoculation of both PPDs (D0) and (ii) three days later, during the reading of comparative tuberculin test (D3). Samples were transported at room temperature to the laboratory and processed within 24 hours from collecting for INF $\gamma$ assay.

INF $\gamma$ assay. The INF $\gamma$ assay was performed by the Bovigam ${ }^{\text {TM }}$ kit (CSL Veterinary, Australia), according to the manufacturer's specifications. Briefly, each blood sample was divided in three aliquots of $1.5 \mathrm{~mL}$, which were distributed into wells of 24-well plates (Sarstedt, Germany). Then, $100 \mu \mathrm{L}$ of bovine PPD (CSL Veterinary, Australia), avian PPD (CSL Veterinary, Australia), or PBS (pH 7.3) were added to one of the wells. Thereafter, plates were incubated at $37^{\circ} \mathrm{C}$, in humidified $5 \% \mathrm{CO}_{2}$ atmosphere, for 24 hours as described by (Rothel et al. 1992). After incubation, plates were centrifuged at $500 \times$ G for $10 \mathrm{~min}$ at $4^{\circ} \mathrm{C}$, and $500 \mu \mathrm{L}$ of plasma from each well were collected, identified and stored 123 at $-20^{\circ} \mathrm{C}$ until assayed, in duplicate, by the INF $\gamma$ Bovigam $^{\mathrm{TM}}$ ELISA.

Statistical analysis. The results of INF $\gamma$ assay on D0 and D3 after tuberculin inoculation and the comparative tuberculin test were compared by the McNemar's test (Siegel 1975) and kappa statistics (Smith 1994). The mean optical density of the results from bovine PPD stimulated blood in the INF $\gamma$ assay on D0 and D3 was compared by the Wilcoxon test (Siegel 1975). Sensitivity and specificity of tests were calculated by a Bayesian latent class model (Dendukuri \& Joseph 2001). Prior distributions for the sensitivity and specificity for comparative tuberculin test (Rothel et al. 1992, Marassi et al. 2010) and INF $\gamma$ assay (Wood \& Jones 2001) were specified from the literature. Parameters for parallel and serial testing were calculated according to Tarabla (Tarabla 2000). Statistical analyses were performed by the statistical packages Epistat (T.L.Gustafson, Round Rock, Texas, USA), WinEpiscope 2.0 (Thrusfield et al. 2001), and BayesLatentClassModels 1.0 (N. 
Dendukuri, P. Bélisle, and L. Joseph, McGill University, Montreal, Canada), with an $\alpha$ error of 0.05 (Sampaio 2002).

\section{RESULTS}

From the 350 cattle submitted to the comparative tuberculin test, 102 were selected to the study: 29 comparative tuberculin test-positive animals from TB-infected herds and 73 comparative tuberculin test-negative animals from TB-free herds. Among the comparative tuberculin test-negative animals, 39 cattle showed cross-reactivity with Mycobacterium avium complex in the comparative tuberculin test (data not shown). Results for the comparative tuberculin test and INF $\gamma$ assay in all 102 animals on D0 and D3 are shown in Table 1.

Table 1. Results of the Comparative Tuberculin Test and INF Assay performed on blood collected on day $\mathbf{0}$, before the inoculation of tuberculin, and on day 3 , at comparative tuberculin test reading, in cattle from tuberculosis-positive and tuberculosis-free herds

\begin{tabular}{lccc}
\hline \multirow{2}{*}{ IFNg Assay } & \multicolumn{3}{c}{ Comparative Tuberculin Test } \\
\cline { 2 - 4 } & Positive & Negative & Total \\
\hline D0* & & & \\
Positive & 24 & 16 & 40 \\
Negative & 5 & 57 & 62 \\
Total & 29 & 73 & 102 \\
D3** & & & \\
Positive & 25 & 11 & 36 \\
Negative & 4 & 62 & 66 \\
Total & 29 & 73 & 102 \\
* $^{*}$ D0 Test performed on blood collected on day 0, before the \\
inoculation of tuberculin. $\chi^{2}$ McNemar $=4.761, \mathrm{P}=0.029, \mathrm{df}$ \\
$\quad=1 .{ }^{* *}$ D3 = Test performed on blood collected at compara- \\
tive tuberculin test reading on day 3. $\chi 2$ McNemar $=2.4, \mathrm{P}=$ \\
0.118, 340 df = 1.
\end{tabular}

There was a significant difference between the performance of the comparative tuberculin test and the INF assay done on D0, however, no difference was found when the results from INF $\gamma$ assay done on D3 were compared (Table 1). The agreement between the two methods was $79.4 \%$ $(\kappa=0.546)$ on D0 and $85.3 \%(\kappa=0.663)$ on D3. If data from animals with cross-reactivity with $M$. avium complex were withdrawn from the analyses, the agreement among the methods rises to $82.5 \%(\kappa=0.649)$ on D0 and $85.7 \%(\kappa=0.713)$ on D3.

No significant differences were found on the mean optical density of the results from bovine PPD stimulated blood in the INF $\gamma$ assay on D0 (mean 1.1671) and D3 (mean 0.9482) $(\mathrm{P}=0.0646)$.

The estimates of sensitivity and specificity for comparative tuberculin test and INF $\gamma$ assay on D0 and on D3 are shown in Table 2. Parameter estimates for multiple testing performed with comparative tuberculin test and INF $\gamma$ assay are shown in Table 3.

Table 3. Estimates of Sensitivity and Specificity of multiple testing performed with Comparative Tuberculin Test and INF $\gamma$ Assay

\begin{tabular}{|c|c|c|c|c|}
\hline \multirow[t]{2}{*}{ Day } & \multicolumn{2}{|c|}{ Parallel Testing (\%) } & \multicolumn{2}{|c|}{ Serial Testing (\%) } \\
\hline & Sensitivity & Specificity & Sensitivity & Specificity \\
\hline D0 * & 97.5 & 90.0 & 68.5 & 99.8 \\
\hline D3 ** & 98.2 & 86.3 & 72.5 & 99.7 \\
\hline
\end{tabular}

* D0 $=$ Test performed on blood collected on day 0 , before the inoculation of tuberculin. ${ }^{* *} \mathrm{D} 3=$ Test performed on blood collected at comparative tuberculin test reading on day 3.

\section{DISCUSSION}

The results of the present study confirm the usefulness of the INF $\gamma$ assay for the diagnosis of bovine tuberculosis and shows that it could be a very useful tool in the context of a control and eradication program, in conjunction with the comparative tuberculin test. On the other hand, INF $\gamma$ assay has some limitations regarding the structure of laboratory and laboratory technicians required for the exams. Another downside of INF $\gamma$ assay cannot be ruled out is the cost of commercial kits, much higher than skin test. However, despite those limitations, the INF $\gamma$ assay can be used from a strategic standpoint. Simulation of its use in multiple testing with the comparative tuberculin test demonstrates that it could help to solve some of the most complicated and strategic situations on a bovine TB-control and eradication program. One of the greatest drawbacks in bovine TB diagnosis is lack of sensitivity of its international standard, the tuberculin test (De La Rua-Domenech et al. 2006, Monaghan et al. 1994, OIE 2009). Most figures showed values around $80 \%$ sensitivity for comparative tuberculin test, similar with the estimations found in this study (Table 2 ), which precludes a rapid evolution of a control program. The use of parallel testing with the INF $\gamma$ assay and the comparative tuberculin test showed much higher rates of sensitivity, as shown by the simulation performed (Table 3). Hence, this strategy could be very useful in the beginning of a control program or for the introduction of animals into free-herds or free-regions, when a very high sensitivity is needed for the diagnosis to increase the negative predictive

Table 2. Estimates of sensitivity and specificity for the Comparative Tuberculin Test and the INF $\gamma$ Assay on the day of inoculation (D0) and on the day of reading (D3) of tuberculin test*

\begin{tabular}{|c|c|c|c|c|c|c|c|c|c|c|c|}
\hline \multirow[t]{3}{*}{ Day } & \multicolumn{6}{|c|}{ Comparative Tuberculin Test } & \multicolumn{5}{|c|}{ IFN $\gamma$ Assay } \\
\hline & \multicolumn{3}{|c|}{ Sensitivity (\%) } & \multicolumn{3}{|c|}{ Specificity (\%) } & \multicolumn{3}{|c|}{ Sensitivity (\%) } & \multicolumn{2}{|c|}{ Specificity (\%) } \\
\hline & Median & $95 \%$ & $\mathrm{CI}^{* *}$ & Median & 95 & CI & Median & $95 \%$ & $\mathrm{CI}$ & Median & $95 \%$ CI \\
\hline $\mathrm{D} 0 * * *$ & 76.7 & 59.7 & 93.7 & 97.8 & 95.7 & 99.0 & 89.3 & 71.7 & 100 & 92.0 & 73.7 \\
\hline D3 $* * * *$ & 79.4 & 60.9 & 93.8 & 97.7 & 95.5 & 98.9 & 91.3 & 72.8 & 100 & 88.3 & 73.4 \\
\hline
\end{tabular}

* All data were calculated by a Bayesian latent class model (Dendukuri \& Joseph 2001), with prior distributions from the literature (Monagham et al. 1994, Wood \& Jones 2001). ${ }^{* *} 95 \% \mathrm{CI}=95 \%$ Credible Interval. ${ }^{* * *} \mathrm{D} 0=$ Test performed on blood collected on day 0 , before the inoculation of tuberculin. ${ }^{* * * *}$ D3 $=$ Test performed on blood collected at comparative tuberculin test reading on day 3. 
value and to reduce the number of false-negative animals, which could introduce the bovine tuberculosis into a new area (Snider 1982, Neill et al. 1994, Whipple et al. 1995, Archetti et al. 1996, Llamazares et al. 1999, Cagiola et al. 2004, Vordermeier et al. 2004).

The use of the INF $\gamma$ assay as a confirmatory test is also advisable by the simulations done, which showed a very high specificity rate when serial testing with the two assays were used (Table 3). Most programs on the control and eradication of bovine TB are based on serial testing with single tuberculin test followed by a confirmatory comparative tuberculin test (Brasil 2006, OIE 2009). If the INF $\gamma$ assay is added to this strategy, as another confirmatory test in the series, a nearly $100 \%$ specificity will be achieved, which is essential in the latest phases of an eradication program or in free-areas to increase the positive predictive value of the diagnosis (Smith 1994, Tarabla 2000).

The sensitivity and specificity values estimated for the INF $\gamma$ assay and for the comparative tuberculin test in the present study are in the range of those reported for these assays in the literature (Monaghan et al. 1994, Wood \& Jones 2001, De La Rua-Domenech et al. 2006). The specificity of the comparative tuberculin test calculated here agrees with previous reports from Brazil (Belchior 2001) that estimated it to be over $95 \%$. Nevertheless, the sensitivity and specificity estimates for the INF $\gamma$ assay showed rates less than that desired for a test to be employed as the sole test in a control and eradication program (Table 2), therefore discouraging its use as a single test in the diagnosis of bovine TB. Previous reports from Brazil found different mean figures for sensitivity and specificity of the INF $\gamma$ assay (Lilenbaum et al. 1999, Marassi et al. 2010) although they are in the same range as the credible interval found in the present study. The way these parameters were calculated on those studies, relatively to the single or comparative cervical tuberculin test, could have accounted for the differences. In contrast, the Bayesian latent class model use in this study prevents the use of a gold standard with imperfect sensitivity and specificity to which all values were relatively calculated (Dendukuri \& Joseph 2001, Dendukuri et al. 2009). Thus, more confident parameters could be estimate, with the advantage of enabling the calculation of credible intervals for the parameters.

An anamnestic response to the comparative tuberculin test was not detect by the INF $\gamma$ assay in the present study as no difference was found in the mean optical density values of INF $\gamma$ assay performed on blood samples before the inoculation of PPD and at tuberculin reading, even though it has been observed in some studies (Rothel et al. 1992, Wood \& Jones 2001). Nevertheless, it has not hindered INF $\gamma$ assay as the major analyses showed no difference between tests performed on samples collected on both days. Thus, the present results of INF $\gamma$ assay performed on blood samples collected from cattle tuberculin-tested three days previously showed that the assay was not affected by recent tuberculin test, confirming recent studies on this conflicting subject (Whipple et al. 1995, Rangen et al. 2009).

One of the major concerns for the use of the INF $\gamma$ assay in large countries, as Brazil, is the time interval from sample collection to laboratory processing of material. Former studies indicate that a strict interval around $8 \mathrm{~h}$ from sampling to laboratory analysis should be used (Rothel et al. 1992, Wood \& Jones 2001). This would preclude its use in areas far from a laboratory, as is the case of the greatest beef producing area in Brazilian Midwest, but the present results showed that even if blood samples were processed within $24 \mathrm{~h}$ from collection, the INF $\gamma$ assay is a very useful test, as suggested by other studies (Ryan et al. 2000, Buddle et al. 2001).

Thus, the INF $\gamma$ assay proved to be a very useful diagnostic method to be incorporate in a control and eradication program for bovine tuberculosis, due to the adaptability of its use to different epidemiological situations. Moreover, the parameters studied here demonstrated that the INF $\gamma$ assay is applicable to frequently tuberculin-tested cattle in areas where blood samples could be processed within $24 \mathrm{~h}$ from collection.

Acknowledgements.- To Elaine M. S. Dorneles for the help with the formatting of the manuscript. This study was supported by Fundação de Amparo à Pesquisa do Estado de Minas Gerais (Fapemig, Belo Horizonte, Brazil), FEP-MVZ Coordenação Preventiva (Belo Horizonte, Brazil), and by Conselho Nacional de Desenvolvimento Tecnológico e Científico (CNPq, Brasília, Brazil). LBL, APRS, RCL, and APL had fellowships from CNPq (Brasília, Brazil). TMA had a fellowship from Coordenação de Aperfeiçoamento do Pessoal de Nível Superior (CAPES, Brasília, Brazil). Also, to INCT-Pecuária the partnership.

\section{REFERENCES}

Archetti I.L., Amadori M., Scaccaglia P., Vezzoli F., Luini M., Fabbi M., Belloli A. \& Sala L. 1996. Impiego del test c-interferon per la diagnosi di tubercolosi bovina in regione Lombardia. La Sel. Vet. 5:329-338.

Belchior A.P.C. 2001. Prevalência, distribuição regional e fatores de risco da tuberculose bovina em Minas Gerais. MSc Dissertation, Universidade Federal de Minas Gerais, Belo Horizonte, MG. 55p.

Brasil 2004. Secretaria de Defesa Agropecuária, Ministério da Agricultura, Pecuária e Abastecimento, Instrução Normativa no 6, de 8 jan. 2004, aprova o Regulamento Técnico do Programa Nacional de Controle e Erradicação da Brucelose e Tuberculose Animal. Diário Oficial da União, Brasília, 12 jan. 2004, Seção 1, p.6-10.

Brasil 2006. Programa Nacional de Controle e Erradicação da Brucelose e da Tuberculose Animal. Ministério da Agricultura, Pecuária e Abastecimento (MAPA), Brasília. 184p.

Buddle B.M., Ryan T.J., Pollock J.M., Andersen P. \& de Lisle G.W. 2001. Use of ESAT- 6 in the interferon $\gamma$ test for diagnosis of bovine tuberculosis following skin testing. Vet. Microbiol. 80:37-46.

Cagiola M., Feliziani F., Severi G., Pasquali P. \& Rutili D. 2004. Analysis of possible factors affecting the specificity of the gamma interferon test in tuberculosis-free cattle herds. Clin. Diag. Lab. Immunol. 11:952-956.

De La Rua-Domenech, Goodchild A.T., Vordermeier H.M., Hewinson R.G., Christiansen K.H. \& Clifton-Hadley R.S. 2006. Ante mortem diagnosis of tuberculosis in cattle: a review of the tuberculin tests, gamma interferon assay and other ancillary diagnostic techniques. Res. Vet. Sci. 81:190-210.

Dendukuri N, Hadgu A. \& Wang L. 2009. Modeling conditional dependence between diagnostic tests: A multiple latent variable model. Statist. Med. 28:441-461.

Dendukuri N. \& Joseph L. 2001. Bayesian approaches to modeling the conditional dependence between diagnostic tests. Biometrics 57:158-167.

Enøe C., Georgiadi M.P. \& Johnson W.0. 2006. Estimation of sensitivity and specificity of diagnostic tests and disease prevalence when the true disease state is unknown. Prev. Vet. Med. 45:1-81.

Lilenbaum W., Schttini J.C., Souza G.N., Ribeiro E.R., Moreira E.C. \& Fonseca L.S. 1999. Comparison between a $\gamma$-INF assay and intradermal tubercu- 
lin test for the diagnosis of bovine tuberculosis in field trials in Brazil. J. Vet. Med. B 46:353-358.

Llamazares O.R.G, Martín C.B.G, Nistal D., de la Puente R.V.A, Domínguez R.L \& Rodríguez F.E.F. 1999. Field evaluation of the single intradermal cervical tuberculin test and the interferon $\gamma$ assay for detection and eradication of bovine tuberculosis in Spain. Vet. Microbiol. 70:55-66.

Marassi C.D., Medeiros L. \& Lilenbaum W. 2010. The use of a gamma-interferon assay to confirm a diagnosis of bovine tuberculosis in Brazil. Acta Tropica 113:199-201.

Monaghan M.L., Doherty M.L., Collins J.D., Kazda J.F. \& Quin P.J. 1994. The tuberculin test. Vet. Microbiol. 40:111-124.

Neill S.D., Cassidy J., Hanna J., Mackie D.P., Pollock J.M., Clements A., Walton E. \& Bryson D.G. 1994. Detection of Mycobacterium bovis infection in skin test-negative cattle with an assay for bovine interferon-gamma. Vet. Rec. 135:134-135.

OIE 2009. Bovine Tuberculosis. In: Manual for diagnostic tests and vaccines for terrestrial animals. World Organization for Animal Health, Paris, p.1-16.

Rangen S.A., Surujballi O.P., Lutze-wallace C. \& Lees V.W. 2009. Is the gamma interferon assay in cattle influenced by multiple tuberculin injections? Can. Vet. J. 50:270-274.

Rothel J.S., Jones S.L., Corner L.A., Cox J.C. \& Wood P.R. 1992. The gamma-interferon assay for diagnosis of bovine tuberculosis in cattle: conditions affecting the production of gamma-interferon in whole blood culture. Aust. Vet. J. 69:1-4.

Ryan T.J, Buddle B.M. \& DeLisle G.W. 2000. An evaluation of the gamma interferon test for detecting bovine tuberculosis in cattle 8 to 28 days after tuberculin skin testing. Res. Vet. Sci. 69:57-61.

Sampaio I.B.M. 2002. Estatística Aplicada à Experimentação Animal. 2aㅡ ed.
Fundação de Ensino e Pesquisa em Medicina Veterinária e Zootecnia, Belo Horizonte. 265p.

Siegel S. 1975. Estatística Não-paramétrica: para as ciências do comportamento. McGraw-Hill, São Paulo. 350p.

Smith R.D. 1994. Veterinary Clinical Epidemiology: A problem-oriented approach. CRC Press, Boca Raton. 234p.

Snider D.E. 1982. The tuberculin skin test. Am. Rev. Resp. Dis. 125:108118.

Tarabla H. 2000. Epidemiolgía Diagnóstica. Universidad Nacional del Litoral, Argentina. 120p.

Thrusfield M., Ortega C., De Blas I., Noordhuizen J.P. \& Frankena K. 2001. Win Episcope 2.0: improved epidemiological software for veterinary medicine. Vet Rec. 148:567-572.

Vordermeier M., Goodchild A., Clifton-Hadley R. \& de la Rua R. 2004. The interferon-gamma field trial: background, principles and progress. Vet. Rec. 155:37-38.

Whipple D.L., Bolin C.A., Davis A.J., Jarnagin J.L., Johnson D.C., Nabors R.S., Payeur J.B., Saari D.A., Wilson A.J. \& Wolf M.M. 1995. Comparison of the sensitivity of the caudal fold skin test and a commercial $\gamma$-interferon assay for diagnosis of bovine tuberculosis. Am. J. Vet. Res. 56:415-419.

Whipple D.L., Palmer M.V., Slaughter R.E. \& Jones S.L. 2001. Comparison of purified protein derivatives and effect of skin testing on results of a commercial gamma interferon assay for diagnosis of tuberculosis in cattle. J. Vet. Diagn. Invest. 13:117-122

Wood P.R., Corner L.A. \& Plackett P. 1990. Development of a simple, rapid in vitro cellular assay for bovine tuberculosis based on the production of gamma-interferon. Res. Vet. Sci. 49:46-49.

Wood P.R. \& Jones S.L. 2001. Bovigam: an in vitro cellular diagnostic test for bovine tuberculosis. Tuberculosis 81:147-155. 